TAKING TURNS WITH THE EARTH 
This page intentionally left blank 


\section{TAKING TURNS WITH THE EARTH}

Phenomenology, Deconstruction, and Intergenerational Justice

Matthias Fritsch 
Stanford University Press

Stanford, California

(C) 2018 by the Board of Trustees of the Leland Stanford Junior University. All rights reserved.

No part of this book may be reproduced or transmitted in any form or by any means, electronic or mechanical, including photocopying and recording, or in any information storage or retrieval system without the prior written permission of Stanford University Press.

Printed in the United States of America on acid-free, archival-quality paper

Library of Congress Cataloging-in-Publication Data

Names: Fritsch, Matthias, author.

Title: Taking turns with the Earth : phenomenology, deconstruction, and intergenerational justice / Matthias Fritsch.

Description: Stanford, California : Stanford University Press, 20I8. I

Includes bibliographical references and index.

Identifiers: LCCN 2018003993 (print) I LCCN 2018005627 (ebook) I ISBN 9781503606968 | ISBN 9781503604940 (cloth : alk. paper) I ISBN 978150360695I (pbk. : alk. paper)

Subjects: LCSH: Environmental ethics. I Future, The-Philosophy. I Social justice-Philosophy. I Phenomenology. I Deconstruction. I Philosophy, Modern-2oth century.

Classification: LCC GE42 (ebook) I LCC GE42 .F75 2018 (print) I DDC I79/.I- dc23

LC record available at https://lccn.loc.gov/20I8003993

Cover design: Rob Ehle

Cover photo: Fog over Erlauf valley and Danube, user "Uoaei1" via Wikimedia Commons 